\title{
HYOTISSA MCGINTYI FOUND IN NORTH CAROLINA [MOLLUSCA, BIVALVIA, GRYPHAEIDAE]
}

\author{
DOUGLAS A. WOLFE
}

109 Shore Drive, Beaufort, NC 28516

ANNE E. FOGLEMAN

PO Box 56, Swepsonville, NC 27359

ARTHUR E. BOGAN

NC State Museum of Natural Sciences, MCS 1626 Research Laboratory Raleigh, NC 27699

Key Words: Hyotissa; North Carolina; oyster; Gryphaeidae.

During a field trip sponsored by the North Carolina Shell Club 19 May 2012, one of us (AEF) found a cluster of three unusual oysters attached to a styrofoam buoy that had drifted to the high tide line on Shackleford Bank, about $5 \mathrm{~km}$ east of Beaufort Inlet, Carteret County, North Carolina. The specimens were recognized (by DAW) as a poorly known Caribbean species not previously reported from North Carolina. Two of the specimens retrieved from the buoy contained dried tissue (seriously contaminated with beach sand); and in the hope that this tissue might yield DNA useful for identification purposes, the specimens were frozen for 11 days before the tissue was finally retrieved and placed in $75 \%$ Ethanol. No useful DNA was extracted from the tissue, however; so the specimens were ultimately identified on the basis of shell characters alone. The specimens (Fig. 1) currently reside in the personal collection of AEF.

Identification of the three specimens proved somewhat elusive, because of prior taxonomic confusion in popular shell-identification guides. A most striking character in the specimens was the prominent saw-toothed margin of the shells, highly reminiscent of the Cock'sComb Oyster [Lopha cristagalli (Linnaeus, 1758)]- a popular collectors item locally common in the IndoPacific (Abbott and Dance 1982). This feature is shared by the common Caribbean "Frond" or "Coon" Oyster, Dendrostrea frons (Linnaeus, 1758), usually found attached to mangrove roots or whip corals; and to a much lesser degree by the "Crested Oyster," Ostreola equestris (Say, 1834), found regularly in shallow offshore waters and high-salinity bays of North Carolina (Abbott and Dance 1982; Abbott 1974; Turgeon et al. 1998). The new NC specimens differed considerably, however, in overall shape, shell color, and shell texture from specimens of D. frons collected previously in Puerto Rico by DAW and from the common $O$. equestris (specimens in the DAW collection and the NCSM, Raleigh collection). Shell texture was the important key feature. Close examination of the interior marginal surfaces of the shells with a hand lens and microscope revealed a spongy or cellular shell structure quite different from the hard nacreous surface typically found in the Ostreidae; and demonstrated conclusively that the specimens were in fact members of the family Gryphaeidae. However, the identification dilemma did not end there.

Both Abbott (1974) and Abbott and Dance (1982) mention only a single species of Gryphaeid in the western Atlantic, but erred in synonymizing that species with its Indo-Pacific relative Hyotissa hyotis (Linnaeus, 1758). This error was recognized and corrected by Turgeon et al. (1998), who listed the species as Parahyotissa mcgintyi Harry, 1985, and further listed a second Gryphaeid species in American waters, Neopycnodonte cochlear (Poli, 1795) —or "Deepsea Oyster"found at depths down to $2,100 \mathrm{~m}$ in tropical Atlantic and Pacific waters. The confusing taxonomic history of the shallow water species was reviewed in detail by Bieler et al. (2004), who corrected the binomial to Hyotissa mcgintyi (Harry, 1985), but also reported the introduction of true Indo-Pacific H. hyotis into Florida waters ( 2 specimens: from $37 \mathrm{~m}$ off the middle Florida Keys; and from $30 \mathrm{~m}$ off West Palm Beach). The identity of their specimen from the Florida Keys was verified by comparisons of mitochondrial 16S DNA from a specimen of $H$. hyotis obtained from Guam, and previously collected $H$. mcgintyi from Florida. The unsuccessful attempt to retrieve DNA from the dried and decomposing tissue in our specimens precluded that certain avenue of identification. While fully adult $H$. hyotissa are readily differentiated from $H$. mcgintyi, the small size of our specimens $(51,35$, and $24 \mathrm{~mm}$, respectively) made this distinction more tenuous. However, our specimens exhibit a creamy white coloration (not dissimilar to that expected in Crassostrea virginica - the Eastern Oyster abundant in our area), but with a deep rosy tinge near the margin of the specimens. The interior of the shells also were of a uniformly light off-white color with some 


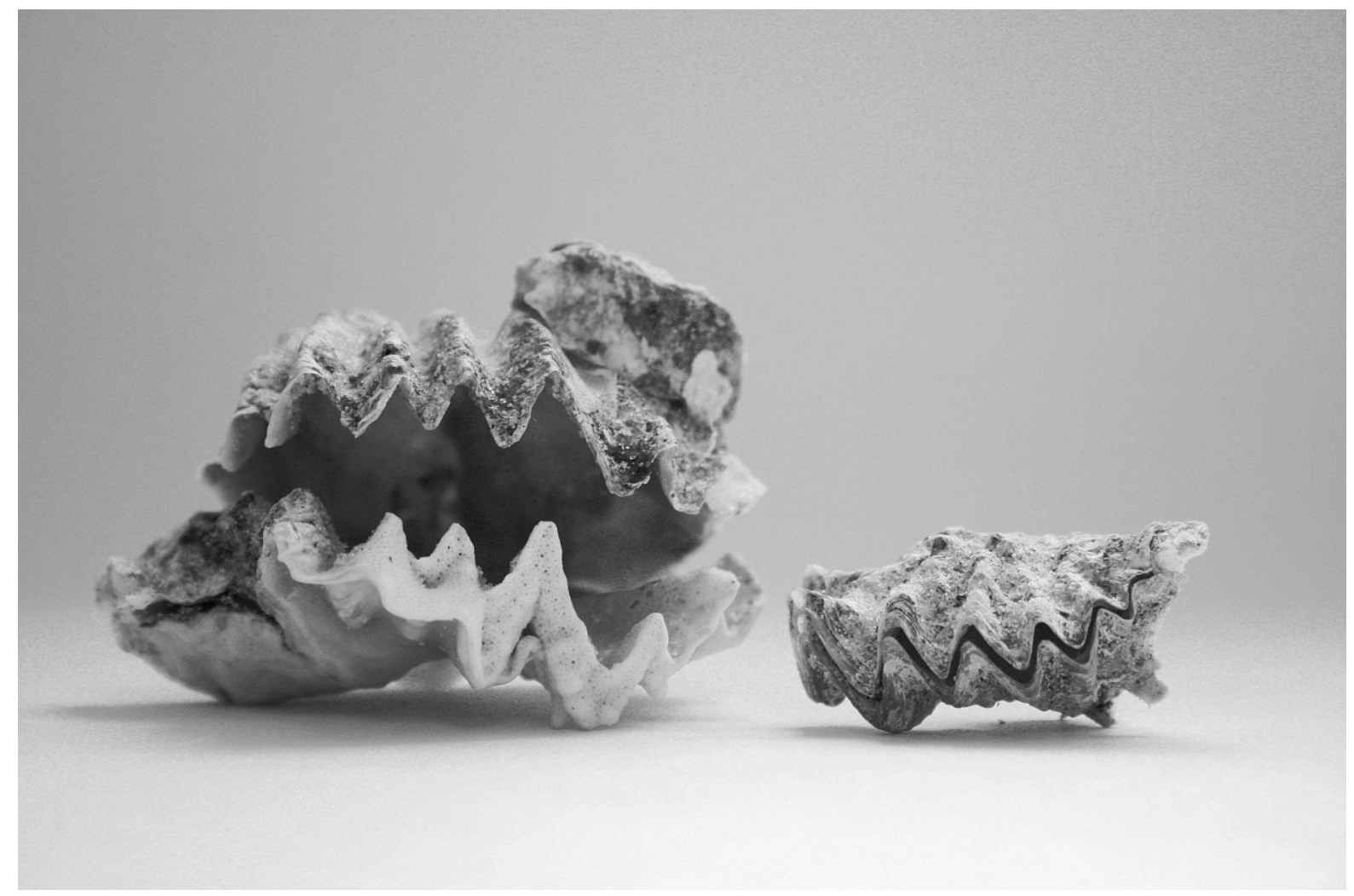

FIG. 1. Specimens of Hyotissa mcgintyi (Harry 1985) from Shackleford Bank, North Carolina. Maximum diameters of the two principal shells are $51 \mathrm{~mm}$ and $35 \mathrm{~mm}$. A third individual is attached on top of the largest specimen. Photo by Anne Fogleman.

darker brown streaks on the interior ridges of the zigzag margin. H. hyotis by contrast typically exhibits a dark purplish-black exterior, which extends well into the interior margins of the shell, surrounding a lighter bluish-white interior portion of the shell and brown staining of the adductor muscle scar. Therefore our specimens were indeed Hyotissa mcgintyi (Harry, 1985).

We note that Bieler et al. (2004) cited Carriker and Gaffney (1996) who in turn cited Harry (1985) for the statement (paraphrased slightly at each step) that the range of $H$. mcgintyi includes "the tropical eastern and western Atlantic Ocean, extending slightly into subtropical areas in the latter realm (to North Carolina and Texas)." Harry (1985) further stated "mcgintyi occurs subtidally and to $98 \mathrm{~m}$ depth or slightly more." No prior records of this species in North Carolina exist. Abbott (1974) gave "Southeast Florida and the West Indies"; Lee (2009) extended the known range to NE Florida with his records from reefs 18-27 m deep and 14-29 km ESE of Mayport, Florida. Rosenberg (2005) gave " $26.7^{\circ} \mathrm{N}$ to $12^{\circ} \mathrm{S} ; 82.5^{\circ} \mathrm{W}$ to $0^{\circ} \mathrm{W}$ ", citing "East Florida" and "Grand Bahama" as the northernmost records. There are no records in the extensive collections made in offshore waters by the University of North Carolina (Porter 1974), now residing in the NC State Museum of Natural Sciences in Raleigh. Thus, the present record, associated though it is with a floating object of unknown origin, is the first state record for the species. We further speculate that habitat highly suitable for this species exists in offshore waters of North Carolina (Menzies et al. 1966) and could in fact already support a resident population that would be easily overlooked with traditional sampling technique. The discovery of introduced H. hyotis in southern Florida (Bieler et al. 2004) could portend the future arrival of that species as well.

The taxonomic confusion surrounding this species is likely to continue. Huber (2010) illustrated it under the name Parahyotissa (Parahyotissa) rosea (J.F. Gmelin, 1791); and introduced this binomial into the World Register of Marine Species (WoRMS 2012). This WoRMS record was subsequently edited (by Philippe Bouchet) to designate $P$. rosea as a nomen oblitum, and thereby returned the binomial to Parahyotissa mcgintyi Harry 1985. We have followed the recommendation of Kirkendale et al. (2004) and Bieler et al. (2004) that no phylogenetic basis existed for recognizing the genus Parahyotissa Harry, 1985 and so have retained Hyotissa Stenzel, 1971 here.

Acknowledgments: We thank Jamie Smith and Cindy Bogan for critical reviews of an earlier draft of this manuscript. 


\section{LITERATURE CITED}

ABBOTT, R. T. 1974. American Seashells: the Marine Mollusca of the Atlantic and Pacific Coasts of North America, 2nd ed. Van Nostrand Reinhold, New York. 663 p. (species \#5280, p. 457).

ABBOTT, R. T., AND S. P. DANCE. 1982. Compendium of Seashells. E.P. Dutton, New York. 411 p.

BIELER, R., P. M. MIKKELSEN, T. LEE, AND D. Ó. FOIGHIL. 2004. Discovery of the Indo-Pacific oyster Hyotissa hyotis (Linnaeus 1758) in the Florida Keys (Bivalvia: Gryphaeidae). Molluscan Res. 24:149-159.

CARRIKER, M. R., AND P. M. GAFFNEY. 1996. A catalogue of selected species of living oysters (Ostreacea) of the world. Pp. 18 in V. S. Kennedy et al. (eds.). The Eastern Oyster. Maryland Sea Grant College; College Park MD.

HARRY, H. W. 1985. Synopsis of the supraspecific classification of living oysters (Gryphaeidae and Ostreidae). The Veliger 28:121-158.

HUBER, M. 2010. Compendium of Bivalves. Conchbooks, Hackenheim, Germany. $901 \mathrm{p}$.

KIRKENDALE, L., T. LEE, P. BAKER, AND D. Ó. FOIGHIL. 2004. Oysters of the Conch Republic (Florida Keys); a
Molecular Phylogenetic Study of Parahyotissa mcgintyi, Teskeyostrea weberi and Ostreola equestris. Malacologia. 46:309-326.

LEE, H. G. 2009. Marine Shells of Northeast Florida. Jacksonville Shell Club, Jacksonville, FL. 204 p.

MENZIES, R. J., O. H. PILKEY, B. W. BLACKWELDER, D. DEXTER, P. HULING, AND L. MCCLOSKEY. 1966. A submerged reef off North Carolina. Int. Revue ges. Hydrobiol. 51(3):393-431.

PORTER, H. J. 1974. The North Carolina marine and estuarine Mollusca: An atlas of Occurrence. Univ. N.C. Inst. Mar. Sci., Morehead City, North Carolina. $351 \mathrm{p}$.

ROSENBERG, G. 2005. Malacolog 4.1.0: A Database of Western Atlantic Marine Mollusca. http://www.malacolog.org/. Last accessed: 20 July 2012.

TURGEON, D. D., et al. 1998. Common and Scientific Names of Aquatic Invertebrates from the United States and Canada: Mollusks, 2nd ed. Am. Fish. Soc. Sp. Publ. 26. 526 p.

WORMS. 2012. World Registry of Marine Species. http://www. marinespecies.org/aphia.php? $\mathrm{p}=$ taxdetails\&id $=542364$ Last accessed 22 July 2012. 